\title{
Correlation and path analysis of Tobacco (Nicotiana tabacum L.) yield vs root traits and relative water content as affected by Azotobacter, mycorrhizal symbiosis and biochar application under dry-land farming conditions
}

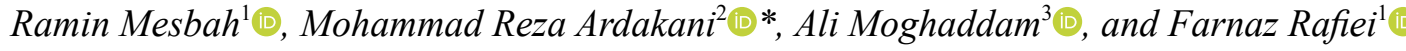 \\ ${ }^{1}$ Department of Agronomy, North Tehran Branch, Islamic Azad University, Tehran, Iran \\ ${ }^{2}$ Department of Agronomy, Karaj Branch, Islamic Azad University, Karaj, Iran \\ ${ }^{3}$ Seed and Plant Improvement Institute (SPII), Agricultural Research, Education and Extension Organization (AREEO), Karaj, Iran
}

Received August 5, 2021; accepted November 15, 2021

\begin{abstract}
The global approach in agriculture is to reduce the use of chemical fertilizers and the supply of nutrients from available sources which are environmentally friendly. In order to evaluate the feasibility of tobacco products without chemical fertilizer inputs, this research was carried out as a factorial experiment based on a $3 \times 2 \times 2$ randomized complete block design which included biochar applied at three levels $\left(0,4\right.$, and $\left.8 \mathrm{t} \mathrm{ha}^{-1}\right)$, mycorrhiza, and Azotobacter at two levels (with and without application) with four replications. According to the results, $4 \mathrm{tha}^{-1}$ biochar increased the dry yield by $22 \%$, the relative water content by $6 \%$, and the root length by $41 \%$ compared to the zero level. However, there was no statistically significant difference between the 4 and $8 \mathrm{t} \mathrm{ha}^{-1}$ application of biochar with regard to most traits. The application of mycorrhiza improved the leaf area index as well as the tobacco root length. Azotobacter significantly increased the root length and nicotine content. The tobacco yield in rain-fed conditions is lower than usual, therefore the combined use of biochar and these biofertilizers may be considered as a viable solution. With increasing interest in the use of environmentally friendly sources of fertilizers and in terms of economic considerations, the use of $4 \mathrm{t} \mathrm{ha}^{-1}$ of biochar along with mycorrhiza and Azotobacter achieved an acceptable yield.
\end{abstract}

Keyw ords: bio-coal, biofertilizers, chemical quality, nicotine content, tobacco

*Corresponding author e-mail: mreza.ardakani@gmail.com

\section{INTRODUCTION}

In recent years, the excessive consumption of chemical fertilizers in combination with increasing production costs has led to the destruction of soil, water and biological resources (Gebhardt et al., 2017). Hence, in order to reduce the traces of chemical fertilizers in the environment and maximize the economic use of fertilizers, biofertilizers are considered to be a promising alternative approach to maintain and impr ove agroecosystems (Gao et al., 2020). These biofertilizers are mainly based on beneficial microorganisms which have the effect of enhancing soil fertility and plant growth by increasing the number and biological activity of useful microorganisms in the rhizosphere (Gao et al., 2020).

Arbuscular mycorrhizal fungi (AMF) are the most effective microbial symbiotic organisms for improving the growth and yield of the majority $(90 \%)$ of plants (Ardakani et al., 2009; Ahanger et al., 2014; Tarnabi et al., 2019). The symbiotic relationship between plants and mycorrhizal constitutes a link between the biotic and the geochemical portions of the ecosystem, and such a relationship may be

(C) 2021 Institute of Agrophysics, Polish Academy of Sciences 
considered to be a bridge connecting the root with the surrounding soil microhabitats (Larsen et al., 2017). Inoculating soil with AMF results in the formation of more constant masses and significantly higher extra-radical hyphal mycelium than the non-AMF-treated soils (Samarbakhsh et al., 2009; Syamsiyah et al., 2018). In low moisture conditions in the soil, the available water for plants is limited (Dai, 2012). Hence, all plant physiological processes such as cell turgidity, photosynthetic processes, growth of the root, tissue and organs are influenced (Sheteiwy et al., 2021). AMF can enhance plant tolerance to various environmental stresses by improving the acquisition of mineral nutrients and water (Baum et al., 2015) and it can also affect the water balance of both amply watered and droughtstressed host plants (Sheteiwy et al., 2021). Moreover, AMF improves the physical and chemical properties of the soil, and in particular, the soil structure. Additionally, AMF symbiosis enhanced the activity of soil microbial enzymes (El-Sawah et al., 2021). The plant growth-promoting rhizobacteria (PGPR) was used for the first time at the end of the 1970s in many key ecosystem processes, in such forms as bio-fertilizers and bio-pesticides (Gao et al., 2020). Recent studies have reported that bio-fertilizers can promote plant growth through nitrogen fixation, phytohormone, phosphate $(\mathrm{P})$, and potassium solubilization (Bashan and de-Bashan, 2005). To reduce the harmful effects of agrochemicals with regard to tobacco leaf quality, the use of biofertilizers and nature-based compounds such as biochar are becoming established as essential agroecological practices for plant production. Biochar is a carbon-rich material obtained by pyrolysis using various biomasses (Major et al., 2010; Soliman et al., 2020). The positive effects of biochar application in improving plant growth are manifested in multiple forms, including the enhancement of the uptake and transport of nutrients (Mehari et al., 2015). Biochar enhances soil properties (soil physicochemical characteristics like $\mathrm{pH}, \mathrm{CEC}$, soil structure), water holding capacity and immobilizes soil environmental pollutants (Abbas et al., 2017; Moosavi et al., 2020). However, the properties of biochar are closely related to its physical and chemical properties. In recent times, biochar has been developed to improve crop production as an environmentally friendly solution to reduce water scarcity problems (Oppong Danso et al., 2020).

The present study hypothesized that biofertilizers and their combination with biochar could increase the tobacco yield in dryland farming conditions. According to limited research concerning the response of tobacco plants to abiotic stresses, including water deficit stress, the combination of three types of non-synthetic and environmentally friendly substances were studied with regard to their effects on tobacco growth, water holding capacity and nicotine content without the use of chemical fertilizers.

\section{MATERIALS AND METHODS}

This study was performed during the spring and summer seasons of 2017 and 2018 at the experimental farm of the Tirtash Tobacco Research and Education Centre, locat-

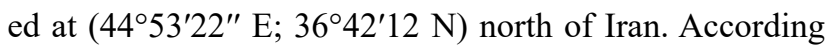
to the 30 -year meteorological statistics, the average rainfall is $622 \mathrm{~mm}$ per year, rain mainly falls in the second half of the year outside the growing season. The average annual maximum and minimum temperature occurs in July $\left(30^{\circ} \mathrm{C}\right)$ and January $\left(5^{\circ} \mathrm{C}\right)$, respectively.

To determine the soil's physical and chemical properties, soil sampling was performed from a depth of 0 to $30 \mathrm{~cm}$ (Table 1).

Biochar chemical analysis results are shown in Table 2.

Azotobacter chroococcum and AMF inoculum were obtained from the Laboratory of Soil and Water Research Institute, Karaj, Iran. The mycorrhizal inoculum included three species Funneliformis mosseae, Rhizophagus irregularis, and Clariodeoglomus etunicatum, with a total population of 70 active spores per gram of biological fertilizer and Azotobacter inoculum with a minimal bacterial density of $10^{7} \mathrm{CFU} \mathrm{g}{ }^{-1}$.

Table 1. Soil physical and chemical properties

\begin{tabular}{ccccccccc}
\hline Year & $\begin{array}{c}\text { Organic } \\
\text { carbon } \\
(\%)\end{array}$ & $\begin{array}{c}\text { Electrical } \\
\text { conductivity } \\
\left(\mathrm{ds} \mathrm{m}^{-1}\right)\end{array}$ & $\begin{array}{c}\text { Chloride } \\
(\%)\end{array}$ & $\begin{array}{c}\text { Absorbable } \\
\text { potassium } \\
(\mathrm{ppm})\end{array}$ & $\begin{array}{c}\text { Phosphorus } \\
(\mathrm{ppm})\end{array}$ & $\begin{array}{c}\text { Total } \\
\text { nitrogen } \\
(\%)\end{array}$ & $\begin{array}{c}\text { Soil } \\
\text { texture }\end{array}$ & $\begin{array}{c}\mathrm{pH} \\
\text { Spandy loam }\end{array}$ \\
\hline 2017 & 1.03 & 0.37 & 0.97 & 220 & 6.9 & 0.089 & Sand \\
2018 & 0.95 & 0.49 & 0.65 & 238 & 10.1 & 0.093 & Sandy loam & 7.6 \\
\hline
\end{tabular}

Table 2. Chemical analysis of biochar

\begin{tabular}{cccccccccc}
\hline \multicolumn{10}{c}{ Elements weight percentage } \\
\hline Silicon & Aluminum & Nitrogen & Iron & Calcium & Potassium & Phosphorous & Magnesium & Oxygen & Carbon \\
\hline 1.43 & 0.19 & 0.31 & 0.43 & 4.27 & 0.38 & 0.18 & 0 & 43.71 & 48.83 \\
\hline
\end{tabular}

Source: Razi Metallurgical Research Center, Karaj, Iran. 
The experiment was carried out as a factorial based on a randomized complete block design $(\mathrm{RCBD})$ with three factors including biochar (B) at three levels: $0,4 \mathrm{t} \mathrm{ha}^{-1}$ (taking the border effect into account, $11 \mathrm{~kg}$ per experimental plot), and $8 \mathrm{t} \mathrm{ha}^{-1}$ (taking the border effect into account, $22 \mathrm{~kg}$ per experimental plot), mycorrhiza (M), and Azotobacter (A) at two levels (with and without application) in four replications for dry yield, root traits, leaf area index, mycorrhizal symbiosis, relative water content and three replications for nicotine content. The flue-cured tobacco pellet seeds (Var. K326) were sown in 220-cell trays with dimensions of 57 $\times 37 \mathrm{~cm}$. For the mycorrhizal treatments, each tray was filled with $2000 \mathrm{~g}$ of soil media containing $10 \%$ of myc orrhizal inoculum before sowing. In treatments containing Azotobacter, ten days before transplantation, the seedling roots were inoculated with an equal volume of inoculum and water solution for an hour. The biochar was scattered over the soil surface and then mixed to a $20 \mathrm{~cm}$ soil depth. Tobacco transplantation and harvest were conducted in May and September (2017 and 2018), respectively. Each plot, with dimensions of $5 \times 4 \mathrm{~m}$, was formed by five rows and 55 tobacco plants spaced at $50 \times 100 \mathrm{~cm}$.

Four to five leaves were harvested at a time and then cured with bulk-curing using the Virginia tobacco curing method. At the end of each harvesting and curing period, tobacco leaves from each plot were weighed separately and the dry weight of the tobacco of each plot was recorded as the dry leaf yield from that particular plot.

In the mid-growing season, relative water content $(R W C)$ was measured using five $1 \times 1 \mathrm{~cm}$ surfaces of new fully expanded leaves of the 13th tobacco leaf. At first, the fresh weight of the samples was determined and then, the samples were floated on distilled water for $12 \mathrm{~h}$ in darkness. The turgid weight was measured. The leaf samples were oven-dried at $75^{\circ} \mathrm{C}$ for $24 \mathrm{~h}$ to calculate their dry weight. $R W C$ was measured using Eq. (1) (Smart and Bingham, 1974):

$$
R W C=\frac{\text { fresh weight }- \text { dry weight }}{\text { turgid weight }- \text { dryweight }} \times 100 .
$$

During the growing season from 45 days after transplanting with a time interval of about 20 days to the last harvest, in five stages for each experimental plot, the plant was randomly selected and, all of its leaves were separated. After measuring its length and width, the leaf area was calculated by applying Eq. (2):

$$
\text { Leaf area }=\text { length } \times \text { width } \times 0.6 \text {. }
$$

After calculating the total area of the plant leaves, the leaf area index was determined in terms of square metres of leaf area per square metre of land. The highest value of the leaf area index was considered to be the maximum leaf area index for analysis.
Root sampling was performed using an auger with a diameter of 10 and a height of $30 \mathrm{~cm}$ (volume: $2355 \mathrm{~cm}^{3}$ ). Soil samples from each plot were soaked in plastic trays for $24 \mathrm{~h}$ to allow the roots to separate more easily from the soil during washing (Antony et al., 2004). The root washing step was performed under water pressure using a 50 mesh plastic filter (pores per inch ${ }^{2}$ ). Their fresh weight was measured in $\mathrm{mg}$ (fresh root weight refers to roots that, after sampling the roots from the soil, are immediately washed with plenty of water, then the root surface water is carefully dried and finally weighed). For the root length trait, only root lengths with a diameter of one millimetre and above were measured.

At the end of the growing season, four root samples from each treatment (one sample from each replication) were isolated and coloured using Phillips and Hayman's (1970) method, and the percentage of colonization was determined using Giovannetti and Mosse's (1980) method.

Leaf nicotine content was measured using the CORESTA recommended method no. 35 (CORESTA, 1994).

The normality of the variables was checked using the Kolmogorov-Smirnov test, and Levine's test was also used to examine the equality of the variances. Duncan's multidomain test at $p<0.05$ level was also used to separate the averages of the dependent variables, which were affected to a significant extent by the treatment. Compound data analysis covering the two-year experiment was completed using SPSS software (Ver. 25). The mean values were compared using Duncan's multiple range test at a $5 \%$ probability level. Correlation and stepwise regression were analysed with SPSS software (Ver. 25), and path analysis was implemented using PATH software.

\section{RESULTS}

The year and the addition of biochar had a significant effect $(p<0.01)$ on tobacco dry yield (Table 3$)$. In the second year, dry leaf yield was $14 \%$ higher than in the first year (Table 4). As the level of biochar consumption increased, the leaf yield also increased. Biochar addition had a gradual beneficial effect on tobacco dry yield however, no significant difference was observed between the 4 (B4) and 8 (B8) $\mathrm{t} \mathrm{ha}^{-1}$ levels. A comparison between the $\mathrm{B} 4$ and $\mathrm{B} 8$ additions showed that the improvement rate in the dry yield due to a doubling in the consumption of biochar was only $7 \%$. Although mycorrhiza and Azotobacter application did not have a significant effect on dry yield, these additions nevertheless increased dry yield by 22 and 3.4\%, respectively.

Relative water content was significantly $(\mathrm{p}<0.01)$ affected by the year being studied and biochar application (Table 3). The greater average value of $R W C$ in the second year could be due to the higher rainfall during the growing season and the lower average monthly temperature compared to the first year. For treatments containing biochar, the average $R W C$ was more than $78 \%$, while the level of this 
Table 3. Analysis of variance for the effect biochar, mycorrhiza and Azotobacter and their interactions on dry yield, relative water content, leaf area index, root fresh weight, root length, mycorrhizal colonization and nicotine (\%)

\begin{tabular}{|c|c|c|c|c|c|c|c|c|c|}
\hline S.O.V. & d.f. & Dry yield & $\begin{array}{c}\text { Relative } \\
\text { water } \\
\text { content }\end{array}$ & $\begin{array}{c}\text { Leaf area } \\
\text { index }\end{array}$ & $\begin{array}{l}\text { Root fresh } \\
\text { weight }\end{array}$ & $\begin{array}{l}\text { Root } \\
\text { length }\end{array}$ & $\begin{array}{l}\text { Mycorrhizal } \\
\text { colonization }\end{array}$ & d.f. & $\begin{array}{c}\text { Nicotine } \\
(\%)\end{array}$ \\
\hline Year & 1 & $28 \times 10^{6 * *}$ & $374.5 * *$ & $11.57 * *$ & $1030 * *$ & $526.9^{\mathrm{ns}}$ & $70.60^{\mathrm{ns}}$ & 1 & $0.561 * *$ \\
\hline r(year) & 6 & $48 \times 10^{3}$ & 1.897 & 0.052 & 6.58 & 318.3 & 28.70 & 4 & 0.006 \\
\hline B: Biochar & 2 & $41 \times 10^{5 * *}$ & $320.5^{* *}$ & $0.935^{\mathrm{ns}}$ & $1362 *$ & $25839 *$ & $72.80 * *$ & 2 & $0.051^{\mathrm{ns}}$ \\
\hline $\mathrm{B} \times \mathrm{Y}$ & 2 & $43 \times 10^{2 \mathrm{~ns}}$ & $0.544^{\mathrm{ns}}$ & $0.225 * *$ & $71.23 * *$ & $456.0^{*}$ & $9.80^{\mathrm{ns}}$ & 2 & $0.009^{\mathrm{ns}}$ \\
\hline M: Mycorrhiza & 1 & $65 \times 10^{5 \mathrm{~ns}}$ & $78.20^{\mathrm{ns}}$ & $2.714^{* *}$ & $1266^{\mathrm{ns}}$ & $18349 *$ & $17888^{*}$ & 1 & $0.028^{\mathrm{ns}}$ \\
\hline$M \times Y$ & 1 & $13 \times 10^{4 \mathrm{~ns}}$ & $83.76^{* *}$ & $0.007^{\mathrm{ns}}$ & $158.5^{\mathrm{ns}}$ & $73.10^{\mathrm{ns}}$ & $46.50^{\mathrm{ns}}$ & 1 & $0.000^{\mathrm{ns}}$ \\
\hline A: Azotobacter & 1 & $19 \times 10^{4 \mathrm{~ns}}$ & $1.919^{\mathrm{ns}}$ & $0.018^{\mathrm{ns}}$ & $2.00^{\mathrm{ns}}$ & $3966^{* *}$ & $13.80^{\mathrm{ns}}$ & 1 & $2.141^{*}$ \\
\hline$A \times Y$ & 1 & $17 \times 10^{3 \mathrm{~ns}}$ & $1.517^{\mathrm{ns}}$ & $0.033^{\mathrm{ns}}$ & $30.63^{\mathrm{ns}}$ & $0.100^{\mathrm{ns}}$ & $11.80^{\mathrm{ns}}$ & 1 & $0.006^{\mathrm{ns}}$ \\
\hline $\mathrm{B} \times \mathrm{M}$ & 2 & $17 \times 10^{4 \mathrm{~ns}}$ & $12.43 *$ & $0.111^{\mathrm{ns}}$ & $29.23^{\mathrm{ns}}$ & $1411^{\mathrm{ns}}$ & $78.20 * *$ & 2 & $0.020 * *$ \\
\hline $\mathrm{B} \times \mathrm{M} \times \mathrm{Y}$ & 2 & $19 \times 10^{4 \mathrm{~ns}}$ & $0.612^{\mathrm{ns}}$ & $0.056^{\mathrm{ns}}$ & $5.26^{\mathrm{ns}}$ & $271.4^{\mathrm{ns}}$ & $10.50^{\mathrm{ns}}$ & 2 & $0.000^{\mathrm{ns}}$ \\
\hline $\mathrm{B} \times \mathrm{A}$ & 2 & $78 \times 10^{3 \mathrm{~ns}}$ & $16.73^{\mathrm{ns}}$ & $0.003^{\mathrm{ns}}$ & $0.90^{\mathrm{ns}}$ & $538.4^{\mathrm{ns}}$ & $1.80^{\mathrm{ns}}$ & 2 & $0.014 *$ \\
\hline $\mathrm{B} \times \mathrm{A} \times \mathrm{Y}$ & 2 & $16 \times 10^{3 \mathrm{~ns}}$ & $16.00^{* *}$ & $0.033^{\mathrm{ns}}$ & $9.15^{\text {ns }}$ & $1422 * *$ & $20.70^{\mathrm{ns}}$ & 2 & $0.000^{\mathrm{ns}}$ \\
\hline $\mathrm{M} \times \mathrm{A}$ & 1 & $18 \times 10^{4 \mathrm{~ns}}$ & $36.66^{\mathrm{ns}}$ & $0.002^{\mathrm{ns}}$ & $145.9^{\mathrm{ns}}$ & $5.9^{\mathrm{ns}}$ & $9.70^{\mathrm{ns}}$ & 1 & $0.031 *$ \\
\hline $\mathrm{M} \times \mathrm{A} \times \mathrm{Y}$ & 1 & $65 \times 10^{4 \mathrm{~ns}}$ & $42.11 * *$ & $0.019^{\mathrm{ns}}$ & $131.3 * *$ & $257.9^{\mathrm{ns}}$ & $19.20^{\mathrm{ns}}$ & 1 & $0.000^{\mathrm{ns}}$ \\
\hline $\mathrm{B} \times \mathrm{M} \times \mathrm{A}$ & 2 & $22 \times 10^{3 \mathrm{~ns}}$ & $7.898^{\mathrm{ns}}$ & $0.044^{*}$ & $32.21^{\mathrm{ns}}$ & $145.4^{\mathrm{ns}}$ & $19.90^{\mathrm{ns}}$ & 2 & $0.026^{* *}$ \\
\hline $\mathrm{B} \times \mathrm{M} \times \mathrm{A} \times \mathrm{Y}$ & 2 & $76 \times 10^{3 \mathrm{~ns}}$ & $6.284^{*}$ & $0.002^{\mathrm{ns}}$ & $19.59 * *$ & $279.8^{\mathrm{ns}}$ & $16.30^{\mathrm{ns}}$ & 2 & $0.000^{\mathrm{ns}}$ \\
\hline Error & 66 & $11 \times 10^{4}$ & 1.833 & 0.026 & 3.54 & 141.2 & 11.60 & 44 & 0.007 \\
\hline C.V. $(\%)$ & - & 10.50 & 1.750 & 9.340 & 6.07 & 11.31 & 18.18 & - & 4.320 \\
\hline
\end{tabular}

$* 0.05, * * 0.01$ significant probability levels, ns non-significant.

Table 4. Main ( \pm SD) of year, biochar, mycorrhiza and Azotobacter on dry yield, relative water content, leaf area index, root fresh weight, root length, mycorrhizal colonization and nicotine percent

\begin{tabular}{|c|c|c|c|c|c|c|c|c|}
\hline Parameter & & $\begin{array}{l}\text { Dry yield } \\
\left(\mathrm{kg} \mathrm{ha}^{-1}\right)\end{array}$ & $\begin{array}{c}\text { Relative } \\
\text { water } \\
\text { content }(\%)\end{array}$ & $\begin{array}{l}\text { Leaf area } \\
\text { index }\end{array}$ & $\begin{array}{l}\text { Root fresh } \\
\text { weight } \\
\left(\mathrm{mg} \mathrm{cm}^{-3}\right)\end{array}$ & $\begin{array}{l}\text { Root length } \\
\left(\mathrm{mm} \mathrm{cm}^{-3}\right)\end{array}$ & $\begin{array}{c}\text { Mycorrhizal } \\
\text { colonization } \\
(\%)\end{array}$ & $\begin{array}{l}\text { Nicotine } \\
(\%)\end{array}$ \\
\hline \multirow{2}{*}{ Year } & 2017 & $2455 \pm 437^{b}$ & $75.1 \pm 3.8^{b}$ & $1.39 \pm 0.30^{b}$ & $11.8 \pm 2.12^{\mathrm{b}}$ & $0.44 \pm 0.15^{\mathrm{a}}$ & $17.8 \pm 3.8^{\mathrm{a}}$ & $1.86 \pm 0.19^{b}$ \\
\hline & 2018 & $2798 \pm 588^{\mathrm{a}}$ & $79.1 \pm 3.6^{\mathrm{a}}$ & $2.08 \pm 0.27^{\mathrm{a}}$ & $14.5 \pm 3.85^{\mathrm{a}}$ & $0.46 \pm 0.12^{\mathrm{a}}$ & $19.5 \pm 4.8^{\mathrm{a}}$ & $2.04 \pm 0.21^{\mathrm{a}}$ \\
\hline \multirow{3}{*}{ Biochar } & B0 & $2228 \pm 397^{\mathrm{b}}$ & $73.5 \pm 3.1^{\mathrm{c}}$ & $1.55 \pm .047^{\mathrm{a}}$ & $10.1 \pm 2.23^{\mathrm{b}}$ & $0.32 \pm 0.05^{\mathrm{c}}$ & $16.9 \pm 2.6^{\mathrm{b}}$ & $1.91 \pm 0.25^{\mathrm{a}}$ \\
\hline & B4 & $2723 \pm 496^{\mathrm{a}}$ & $78.2 \pm 3.1^{\mathrm{b}}$ & $1.77 \pm 0.42^{\mathrm{a}}$ & $13.9 \pm 2.65^{\mathrm{a}}$ & $0.45 \pm 0.10^{\mathrm{b}}$ & $19.8 \pm 5.5^{\mathrm{a}}$ & $1.95 \pm 0.22^{\mathrm{a}}$ \\
\hline & B8 & $2928 \pm 507^{\mathrm{a}}$ & $79.5 \pm 2.8^{\mathrm{a}}$ & $1.89 \pm 0.40^{\mathrm{a}}$ & $15.5 \pm 2.76^{\mathrm{a}}$ & $0.56 \pm 0.10^{\mathrm{a}}$ & $19.3 \pm 4.9^{\mathrm{a}}$ & $2.00 \pm 0.17^{\mathrm{a}}$ \\
\hline \multirow{2}{*}{ Mycorrhiza } & M0 & $2365 \pm 396^{\mathrm{a}}$ & $76.2 \pm 4.4^{\mathrm{a}}$ & $1.57 \pm 0.40^{\mathrm{b}}$ & $11.6 \pm 2.65^{\mathrm{a}}$ & $0.39 \pm 0.10^{\mathrm{b}}$ & $5.0 \pm 1.8^{\mathrm{b}}$ & $1.93 \pm 0.20^{\mathrm{a}}$ \\
\hline & M1 & $2887 \pm 546^{\mathrm{a}}$ & $78.0 \pm 3.4^{\mathrm{a}}$ & $1.91 \pm 0.43^{\mathrm{a}}$ & $14.7 \pm 3.37^{\mathrm{a}}$ & $0.50 \pm 0.14^{\mathrm{a}}$ & $32.3 \pm 5.5^{\mathrm{a}}$ & $1.97 \pm 0.24^{\mathrm{a}}$ \\
\hline \multirow{2}{*}{ Azotobacter } & A0 & $2581 \pm 553^{\mathrm{a}}$ & $76.9 \pm 3.7^{\mathrm{a}}$ & $1.73 \pm 0.46^{\mathrm{a}}$ & $13.2 \pm 3.76^{\mathrm{a}}$ & $0.42 \pm 0.13^{b}$ & $18.3 \pm 4.1^{\mathrm{a}}$ & $1.78 \pm 0.13^{\mathrm{b}}$ \\
\hline & A1 & $2671 \pm 532^{\mathrm{a}}$ & $77.2 \pm 4.3^{\mathrm{a}}$ & $1.75 \pm 0.44^{\mathrm{a}}$ & $13.2 \pm 3.01^{\mathrm{a}}$ & $0.47 \pm 0.14^{\mathrm{a}}$ & $19.0 \pm 4.7^{\mathrm{a}}$ & $2.12 \pm 0.13^{\mathrm{a}}$ \\
\hline
\end{tabular}

Mean $( \pm \mathrm{SD})$ with a common letter in the same column do not differ significantly at $\mathrm{p}<0.05$.

parameter in non-biochar treatments was $73.5 \%$ (Table 4 ). The interaction between biochar and mycorrhiza was significant at a level of 5\% (Table 3), and with the increasing consumption of biochar and mycorrhiza, the relative water content also increased. The lowest and highest values with 72.5 and $80.1 \%$, are related to BM0 and B8M1, respective- ly (Table 5). There was no significant difference in $R W C$ between the application of mycorrhiza and Azotobacter (Table 3).

The combined analysis of variance showed that the effect of the year being studied and mycorrhiza on leaf area index was significant at 1\% (Table 3). Accordingly, 
Table 5. Mean ( \pm SD) of biochar and mycorrhiza interaction effects on relative water content, nicotine percent and mycorrhizal colonization

\begin{tabular}{|c|c|c|c|c|}
\hline \multicolumn{2}{|c|}{ Experimental treatments } & \multirow{2}{*}{$\begin{array}{c}\text { Relative water content } \\
\qquad(\%)\end{array}$} & \multirow{2}{*}{$\begin{array}{l}\text { Nicotine } \\
(\%)\end{array}$} & \multirow{2}{*}{$\begin{array}{c}\text { Mycorrhizal } \\
\text { colonization } \\
(\%)\end{array}$} \\
\hline Biochar & $\begin{array}{l}\text { Mycorrhizal } \\
\text { status }\end{array}$ & & & \\
\hline \multirow{2}{*}{ No application } & $-\mathrm{AMF}$ & $72.5 \pm 3.36^{\mathrm{d}}$ & $1.91 \pm 0.18^{\mathrm{abc}}$ & $5.07 \pm 1.89^{c}$ \\
\hline & $+\mathrm{AMF}$ & $74.5 \pm 2.34^{\mathrm{c}}$ & $1.92 \pm 0.29^{\mathrm{bc}}$ & $28.83 \pm 5.02^{b}$ \\
\hline \multirow{2}{*}{$4 \mathrm{tha}^{-1}$} & $-\mathrm{AMF}$ & $76.8 \pm 3.39^{\mathrm{ab}}$ & $1.87 \pm 0.20^{\mathrm{c}}$ & $4.94 \pm 1.64^{c}$ \\
\hline & $+\mathrm{AMF}$ & $80.0 \pm 2.58^{\mathrm{a}}$ & $1.98 \pm 0.22^{\mathrm{ab}}$ & $34.63 \pm 5.07^{\mathrm{a}}$ \\
\hline \multirow{2}{*}{$8 \mathrm{tha}^{-1}$} & $-\mathrm{AMF}$ & $79.3 \pm 3.44^{\mathrm{a}}$ & $1.99 \pm 0.17^{\mathrm{ab}}$ & $5.04 \pm 1.55^{\mathrm{c}}$ \\
\hline & $+\mathrm{AMF}$ & $80.1 \pm 2.08^{\mathrm{a}}$ & $2.01 \pm 0.16^{\mathrm{a}}$ & $34.49 \pm 4.85^{\mathrm{a}}$ \\
\hline
\end{tabular}

Mean $( \pm \mathrm{SD})$ with a common letters in the same column do not differ significantly at $\mathrm{p}<0.05$. AMF - arbuscular mycorrhizal fungi. Other explanations as in Table 4.

the average of this parameter in the second year was about $50 \%$ higher than in the first year (Table 4 ). The use of biochar did not have a significant effect on $\mathrm{LAI}_{\max }$ (Table 4). Mycorrhiza application also resulted in a $22 \%$ increase in $\mathrm{LAI}_{\max }$ compared to its non-application (Table 4). The $\mathrm{B} \times \mathrm{M} \times \mathrm{A}$ interaction effect was also significant for $\mathrm{LAI}_{\max }$ at a $5 \%$ level (Table 3). However, the lowest $\mathrm{LAI}_{\max }$ level belonged to B0M0A1 with a value of 1.40 , and the highest level was related to B8M1A0 with a value of 2.13 (Table 5).

The results showed that the year being studied and biochar application had a significant effect on the fresh weight of the root at 1 and $5 \%$, respectively (Table 3 ). The average fresh root weight in the first year was 11.8 and in the second year it was $14.5 \mathrm{mg} \mathrm{cm}^{-3}$ (Table 4). Even though there was no statistically significant difference between B4 and $\mathrm{B} 8$, the highest root fresh weight was obtained in treatments with the application of $8 \mathrm{tha}^{-1}$ of biochar producing, a value of $15.5 \mathrm{mg} \mathrm{cm}^{-3}$ and the lowest value of $10.1 \mathrm{mg} \mathrm{cm}^{-3}$ for the non-biochar treatments (Table 4). The root fresh weight for B8 compared to B4 and B0 showed an increase of 11 and 52\%, respectively (Table 4). Although the root fresh weight was $27 \%$ (Table 4 ) higher for the mycorrhizacontaining treatments, this increase was not statistically significant (Table 3). In this study, biochar and mycorrhiza application had a significant effect on root length, increasing it by $5 \%$ (Table 3 ). Root length was continually enhanced by increasing the biochar application dosage from 4 to $8 \mathrm{t}$ $\mathrm{ha}^{-1}$ in the soil which caused a 41 and $75 \%$ increase compared to the no biochar application, respectively (Table 4). The application of mycorrhiza increased root length by $30 \%$ (Table 4). Tobacco root length showed a significant increase $(\mathrm{p}<0.01)$ in response to Azotobacter application (Table 3), and treatments containing Azotobacter produced root lengths approximately $13 \%$ longer than the non-Azotobacter treatments (Table 4).

The colonization rate was positively affected and increased $(p<0.01)$ by biochar application (Table 3$)$ but not by enough, with results varying from 16.9 to $19.8 \%$.
There was no statistically significant difference between B4 and B8 (Table 4). The highest root mycorrhizal colonization rate with no significant difference was observed in B4 and B8. The mycorrhizal inoculum significantly $(p<0.05)$ increased the extent of root colonization as compared to the non-inoculated treatments (Table 3). In our study, although symbiosis was found to occur to a limited extent in natural soil conditions, fungal inoculum increased this symbiosis with roots by a factor of several times. In this regard, the application of mycorrhiza greatly enhanced the average colonization rate from 5 to $32 \%$ (Table 4 ). Also, the simultaneous application of biochar and mycorrhizal inoculum significantly $(p<0.01)$ improved the colonization of tobacco root with fungi and caused approximate increases in root colonization from 5.1 to $34.5 \%$ (Table 5).

The year of the study had a significant effect $(p<0.01)$ on nicotine content. The average percentage of nicotine in the first year was 1.86 , which was enhanced by approximately $10 \%$ in the second year to $2.04 \%$ (Table 4 ). Also, Azotobacter had a significant $(\mathrm{p}<0.05)$ influence and the most considerable effect on nicotine content was observed with an increase of $20 \%$ (Table 4 ). The simultaneous use of biochar and mycorrhiza, biochar and Azotobacter, as well as mycorrhiza and Azotobacter had a significant effect on leaf nicotine content (Table 3). For treatments containing biochar and mycorrhiza, biochar and Azotobacter, and also mycorrhiza and Azotobacter, the highest amount of nicotine is related to B8M1 (Table 5), B8A1 (Fig. 1), and M1A1 (Fig. 2), respectively. The triple effect of experimental factors had a significant effect on nicotine content at the level of $1 \%$ (Table 3), which varied between 1.66 and $2.17 \%$ in B0M1A0 and B4M1A1, respectively (Table 6).

\section{DISCUSSION}

For tobacco, the quantitative yield is one of the most critical indicators for evaluation, so the utilization of correct management methods to achieve this may be considered to be a scientific solution. In this study, biochar application promoted growth, but for higher amounts of 


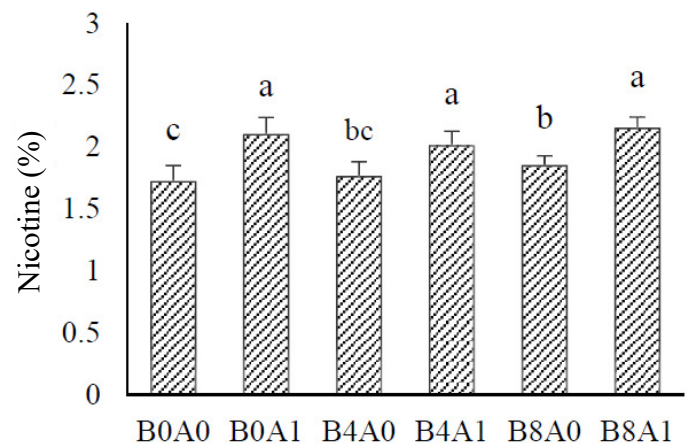

Fig. 1. Effect of biocbar and Azotobacter on nicotine (\%). $\mathrm{BO}$ - no biochar application, B4 - application $4 \mathrm{t} \mathrm{ha}^{-1}$ of biochar, B8 - application $8 \mathrm{t} \mathrm{ha}^{-1}$ of biochar, AO - no Azotobacter application and $\mathrm{Al}-$ Azotobacter application. Means with the same letter are not significantly different.

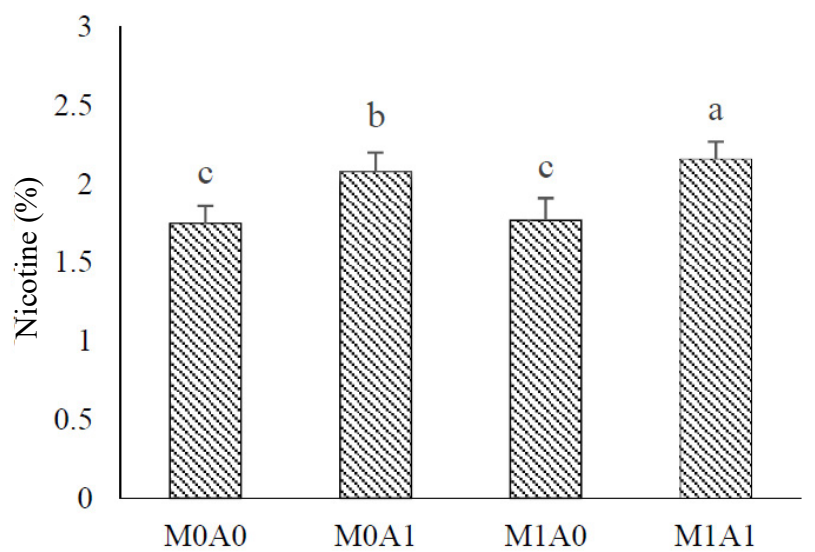

Fig. 2. Effect mycorrhiza and Azotobacter interaction on leaf nicotine content, $\mathrm{MO}$ - no mycorrhiza application, Ml - mycorrhiza application, AO - no Azotobacter application and A1 - Azotobacter application. Means with the same letter are not significantly different.

Table 6. Mean $( \pm \mathrm{SD})$ of biochar, mycorrhiza and Azotobacter interaction effects on leaf area index and nicotine percent

\begin{tabular}{|c|c|c|c|c|}
\hline \multicolumn{3}{|c|}{ Experimental treatments } & \multirow{3}{*}{ Leaf area index } & \multirow{3}{*}{$\begin{array}{l}\text { Nicotine } \\
(\%)\end{array}$} \\
\hline \multirow{2}{*}{ Biochar } & \multicolumn{2}{|c|}{ Status } & & \\
\hline & Mycorrhiza & Azotobacter & & \\
\hline \multirow{4}{*}{ No application } & \multirow{2}{*}{$-\mathrm{AMF}$} & $-A z$ & $1.47 \pm 0.489^{\text {cd }}$ & $1.78 \pm 0.10^{\mathrm{bc}}$ \\
\hline & & $+\mathrm{Az}$ & $1.40 \pm 0.464^{\mathrm{d}}$ & $2.06 \pm 0.13^{\mathrm{a}}$ \\
\hline & \multirow{2}{*}{$+\mathrm{AMF}$} & $-\mathrm{Az}$ & $1.63 \pm 0.492^{\mathrm{cd}}$ & $1.66 \pm 0.14^{\mathrm{c}}$ \\
\hline & & $+\mathrm{Az}$ & $1.71 \pm 0.466^{\mathrm{bc}}$ & $2.16 \pm 0.14^{\mathrm{a}}$ \\
\hline \multirow{4}{*}{$4 \mathrm{t} \mathrm{ha}^{-1}$} & \multirow{2}{*}{$-\mathrm{AMF}$} & $-\mathrm{Az}$ & $1.58 \pm 0.506^{\mathrm{cd}}$ & $1.72 \pm 0.12^{\mathrm{bc}}$ \\
\hline & & $+\mathrm{Az}$ & $1.66 \pm 0.391^{\mathrm{bcd}}$ & $2.04 \pm 0.11^{\mathrm{a}}$ \\
\hline & \multirow{2}{*}{$+\mathrm{AMF}$} & $-\mathrm{Az}$ & $1.93 \pm 0.418^{\mathrm{ab}}$ & $1.83 \pm 0.11^{\mathrm{bc}}$ \\
\hline & & $+\mathrm{Az}$ & $1.92 \pm 0.308^{\mathrm{ab}}$ & $2.17 \pm 0.11^{\mathrm{a}}$ \\
\hline \multirow{4}{*}{$8 \mathrm{tha}^{-1}$} & \multirow{2}{*}{$-\mathrm{AMF}$} & $-\mathrm{Az}$ & $1.61 \pm 0.198^{\mathrm{cd}}$ & $1.86 \pm 0.07^{\mathrm{b}}$ \\
\hline & & $+\mathrm{Az}$ & $1.70 \pm 0.344^{\mathrm{bc}}$ & $2.14 \pm 0.10^{\mathrm{a}}$ \\
\hline & \multirow{2}{*}{$+\mathrm{AMF}$} & $-\mathrm{Az}$ & $2.13 \pm 0.367^{\mathrm{a}}$ & $1.89 \pm 0.85^{\mathrm{b}}$ \\
\hline & & $+\mathrm{Az}$ & $2.12 \pm 0.406^{\mathrm{a}}$ & $2.15 \pm 0.88^{\mathrm{a}}$ \\
\hline
\end{tabular}

Explanations as in Table 4.

biochar addition $\left(8 \mathrm{t} \mathrm{ha}^{-1}\right)$, no significant increment was observed. Some researchers have reported that biochar increases plant growth, biomass, and the absorption of nutrients in water deficit conditions (Kim et al., 2019). Under low humidity conditions, biochar modification limited these adverse effects through its enormous surface area resulting in enhanced soil porosity and aeration, improvements in water holding capacity and the conservation of the water due to the porosity of biochar (Suliman et al., 2017). Despite the insignificant effect of mycorrhiza on increasing tobacco yield revealed by this study, an increase of more than $500 \mathrm{~kg} \mathrm{ha}^{-1}$ of dry yield was achieved with the applica- tion of mycorrhiza. Several previous studies have shown that mycorrhiza plays the role of secondary roots and can reduce the effects of water deficit stress by raising the water and nutrient content in plant tissues (Behrooz et al., 2019).

It has been reported that biochar mixing with the soil can affect soil physical properties such as structure, pore distribution and density, water holding capacity and plant growth (Downie et al., 2009). The positive effects of biochar application to agricultural soils are linked to changes in the physical and chemical parameters of the soil leading 


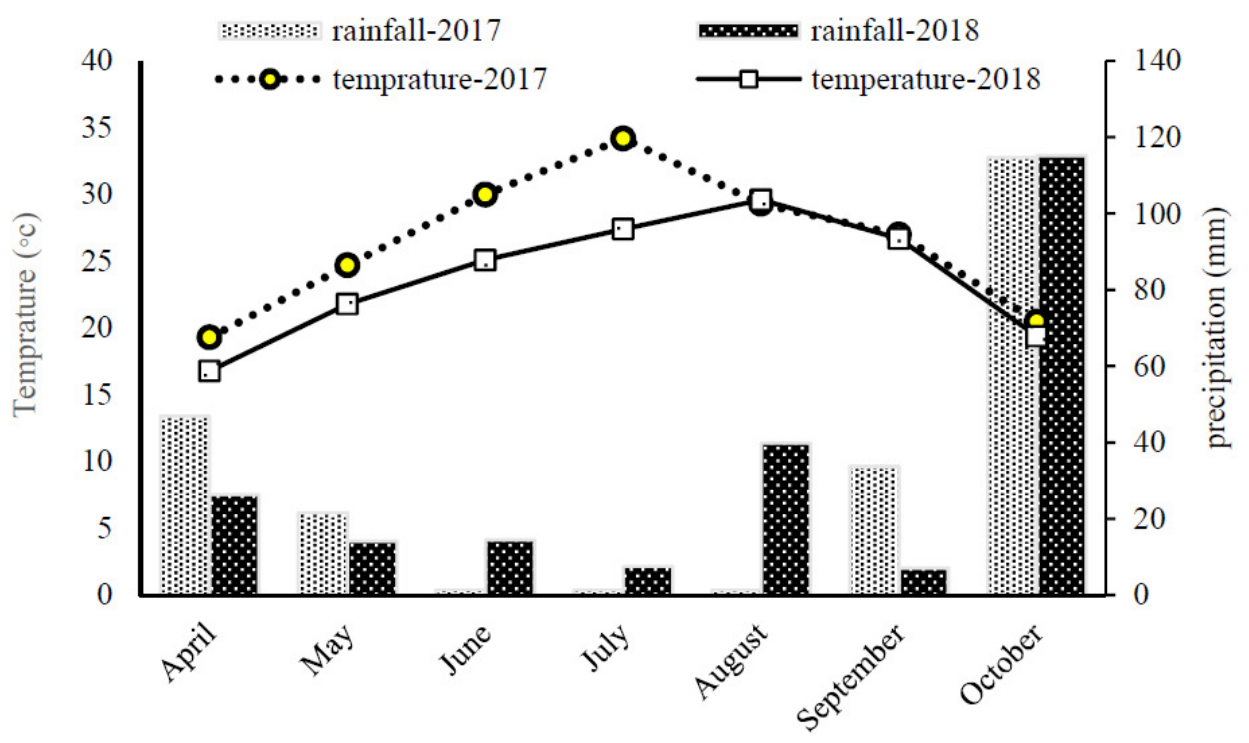

Fig. 3. Temperature and precipitation distribution (2017-2018).

to increased water-holding capacity, which improves the plant's access to soil water resources and thus improves the plant's water status (Laird, 2008).

An increase in $R W C$ due to mycorrhiza application may be attributed to primary drought-avoidance mechanisms, such as increased water uptake related to mycorrhizal changes in root morphology or the active water transfer from mycorrhizal fungi to the host (Miri et al., 2013). The combined application of biochar and AMF had a positive and significant effect on the relative water content (Table 3). Similar results have been reported by Hashem et al. (2019), showing that the combined application of AMF and biochar significantly increased the relative water content.

The results obtained in the present study revealed that all of the variables related to leaf area increased due to mycorrhizal inoculation. The observed enhancement in leaf area characteristics due to AMF inoculation confirms the results of previous studies. In particular, mycorrhizal inoculation increased the leaf area and leaf area ratio (LAR) of Carica papaya by 64 and 54\%, respectively (Alarcón et al., 2002). Moreover, the leaf area of Leucaena leucocephala increased by $161 \%$ due to inoculation (Dixon et al., 1993). Increasing the water absorption capacity of mycorrhizal plants increases the extent of swelling of their cells, which is a stimulus for cell elongation (Wu et al., 2009). In this study, the triple interaction of biochar addition, as well as mycorrhiza and Azotobacter on leaf area index was also positive and significant. Simultaneous biochar and biofertilizer application can also be a beneficial decision in drought conditions to stimulate host plant growth and thus is effective in increasing leaf area index (Ilkaee et al., 2011; Sharma, 2002).

Improvements in root-related traits in the second year may be due to the prevailing optimal growth conditions as compared to the first year, including rainfall during the growing season and the low average monthly temperature (Fig. 3). In this study, the positive effect of biochar application on fresh weight and root length was observed. In this regard, it was shown that biochar increases the root length in annual plants, but the increase in root length depends on the time of use of the biochar and the species of plant in question (Xiang et al., 2017). Other studies have shown that drought stress significantly reduced root length. Moreover, the use of biochar improves root length and depth, so it may be considered as a suitable alternative for increasing plant growth and productivity under drought stress (Hashem et al., 2019). Results indicate that the co-amendment of biochar with other organic fertilizers has a more significant and positive influence on plant root growth and increased root biomass by $20-28 \%$ (Gul and Whalen, 2016). Biofertilizers effectively increase root length by increasing nutrient uptake, this is followed by more leaf photosynthesis and the allocation of more carbon to the roots (Azimi et al., 2013).

The symbiosis of mycorrhizal fungi with plant roots, which has been identified by a sequence of biological functions, has a positive and beneficial impact on agroecosystems (Mardukhi et al., 2015; Van der Heijden et al., 2015). In this study, biochar and mycorrhiza application demonstrated a significant effect on the cloning rate of the fungus within the tobacco root system. The change in the frequency of mycorrhiza in the presence of biochar has been explained by certain mechanisms: biochar changes the ability of plants to gain access to soil nutrients, it plays a role in altering the activity of other microorganisms, or changes the signalling processes between the plant and the fungus. The effect of biochar in root colonization is related to improvements in the growth of fungal hyphae under water deficit conditions (Mickan et al., 2014). The indirect 
Table 7. Pearson correlation coefficients for dry yield (DR), root fresh weight (RFW), root length (RL), leaf area index max (LAI max), relative water content $(R W C)$, mycorrhizal symbiosis $(\mathrm{MS})$ and nicotine content $(\mathrm{NC})$

\begin{tabular}{lcccccc}
\hline & $\mathrm{DR}$ & $\mathrm{RFW}$ & $\mathrm{RL}$ & $\mathrm{LAI}_{\max }$ & $R W C$ & $\mathrm{MS}$ \\
\hline $\mathrm{DR}$ & 1 & & & & & \\
$\mathrm{RFW}$ & $0.740 * *$ & 1 & & & & \\
$\mathrm{RL}$ & $0.667 * *$ & $0.762 * *$ & 1 & & & \\
$\mathrm{LAI}_{\max }$ & $0.638 * *$ & $0.638 * *$ & $0.463 * *$ & 1 & & \\
$R W C$ & $0.312 * *$ & $0.352 * *$ & $0.519 * *$ & -0.105 & 1 & 1 \\
$\mathrm{MS}$ & $0.532 * *$ & $0.525 * *$ & $0.493 * *$ & $0.448 * *$ & $0.270 * *$ & \\
$\mathrm{NC}$ & $0.326 * *$ & $0.291 * *$ & $0.371 * *$ & $0.415 * *$ & -0.088 & 0.140 \\
\hline
\end{tabular}

$*_{\mathrm{p}}<0.01$ significant probability level.

effect of biochar addition on increasing fungal propagation in roots and soil may be due to the cumulative effect on root growth (Hammer et al., 2015).

The chemical composition of tobacco leaves determines their quality. The most valuable quality assessment criterion in tobacco is nicotine content (Shang et al., 2017), this substance is used in the pharmaceutical industry and agricultural pesticides (Baldwin, 2001). In tobacco, nicotine is synthesized by the roots and transferred to the aerial organs, especially to the leaves (Shang et al., 2017). The tobacco leaf nicotine content is closely dependent on soil conditions. This alkaloid is affected by the soil nitrogen content provided by biofertilizers. Inoculation with Azotobacter chroococcum, like $\mathrm{N}$ fertilization significantly increased the $\mathrm{N}$ uptake by the tobacco plants. The increases in $\mathrm{N}$ uptake due to Azotobacter inoculations may be explained by considering the possible mechanisms of $\mathrm{N}$ fixation and growth hormone production (Azcon and Barea, 1976). Azotobacter chroococcum is an aerobic microorganism that fixes molecular $\mathrm{N}$ under different physiological conditions (Saribay, 2003). With regard to the nicotine of leaves, our results showed that $\mathrm{N}$ inoculation with $A$. chroococcum significantly increased nicotine concentrations in tobacco leaves. This result confirms the results of previous studies performed by Ju et al. (2008). Tso (1990) reported that in flue-cured tobacco leaf tissue, $\mathrm{N}$ concentration was positively correlated with leaf nicotine content.

The dry yield had significant positive correlations $(p<0.01)$ with all of the evaluated traits (Table 7$)$. The closest correlation was observed between RFW and dry yield, suggesting an elevated dry yield with increases in the fresh weight of the root due to greater access to water resources, improving the relative water content, providing more favourable conditions for tobacco leaf growth, and finally, leading to an elevated dry yield. Pasban Eslam et al. (2017) studied the correlation between yield and physiological traits and reported that rapeseed genotypes with a higher $R W C$ produced relatively higher yields under drought stress conditions. Stepwise regression was used to eliminate the effects of ineffective or less effective traits on dry yield in the regression model. Among the studied traits, root fresh weight, leaf area index, and relative water content were entered into Eq. (3), respectively (Table 8):

$$
Y=-1234+27 X_{1}+465 X_{2}+29 X_{3},
$$

where: $Y$ is the dry yield, and $X_{1}, X_{2}$, and $X_{3}$ denote root fresh weight, leaf area index, and relative water content, respectively. The model had an $\mathrm{R}^{2}$ of 0.609 , meaning that these traits account for more than $60 \%$ of dry yield variations. The root fresh weight alone accounts for $54 \%$ of dry yield variations (Table 8). The root fresh weight was introduced earlier in the model than the other traits and had the closest correlation ( 0.74$)$ with seed yield (Table 7$)$. The addition of other variables to the model did not significantly influence any further increase in $\mathrm{R}^{2}$. Root fresh weight had the most significant direct and positive effect $(0.402)$ on dry yield (Table 9). This trait had the most pronounced indirect effect

Table 8. Stepwise regression for dry yield (dependent variable) and the other traits (independent variable)

\begin{tabular}{lrrr}
\hline $\begin{array}{l}\text { Added trait } \\
\text { to model }\end{array}$ & 1 & 2 & \multicolumn{1}{c}{3} \\
\hline Intercept & 1070 & 906 & -1234 \\
RFW & 50 & 39 & 27 \\
$\mathrm{LAI}_{\max }$ & & 301 & 465 \\
$R W C$ & & & 29 \\
$\mathrm{R}^{2}$ & 0.55 & 0.58 & 0.61 \\
\hline
\end{tabular}

Root fresh weight (RFW), leaf area index max $\left(\mathrm{LAI}_{\max }\right)$, relative water content $(R W C)$.

Table 9. Path analysis showing direct and indirect effects on the dry yield

\begin{tabular}{lccc}
\hline Trait & RFW & LAI & $R W C$ \\
\hline RFW & $\underline{0.402}$ & 0.264 & 0.074 \\
LAI $_{\max }$ & 0.275 & $\underline{0.386}$ & -0.022 \\
$R W C$ & 0.142 & -0.041 & $\underline{0.211}$ \\
& Residual effect $=0.625$ & \\
\hline
\end{tabular}

Underlined values have direct effects. Other explanations as in Table 8 . 
on dry yield through LAI (0.264) and $R W C(0.074)$, respectively. $R W C$ exerted the least direct influence $(0.211)$ and the lowest indirect effect $(0.142$ and -0.041$)$ on dry yield.

\section{CONCLUSIONS}

1. The results showed that biochar improved the tobacco dry yield by significantly increasing leaf water content, further leaf area expansion, and root development.

2. Application of mycorrhiza while improving plant water status increased tobacco yield. Also, root length was increased with the application of biofertilizers.

3. The Azotobacter also significantly increased the nicotine content of the leaves.

4. The results of this study showed that the application of biochar with improved yield and biofertilizers with increasing growth characteristics and chemical properties could be recommended for use in dryland conditions.

\section{ACKNOWLEDGEMENTS}

Special thanks to Tirtash Tobacco Research and Education Centre.

Conflict of interest: The authors declare that there are no conflicts of interest.

\section{REFERENCES}

Abbas T., Rizwan M., Ali S., Rehman M.Z., Qayyum M.F., Abbas F., Hannan F., Rinklebe J., and Ok Y.S., 2017. Effect of biochar on cadmium bioavailability and uptake in wheat (Triticum aestivum L.) grown in soil with aged contamination. Ecotoxicol Environ. Saf., 140, 37-47. https:// doi.org/10.1016/j.ecoenv.2017.02.028.

Ahanger M.A., Tyagi S.R., Wani M.R., and Ahmad P., 2014. Drought Tolerance: Role of organic osmolytes, growth regulators, and mineral nutrients. In: Physiological Mechanisms and Adaptation Strategies in Plants Under Changing Environment (Eds P. Ahmad, M.R. Wani). Springer, New York, USA. https://doi.org/10.1007/978-1-4614-8591-9_2

Alarcón A., Davies Jr F.T., Egilla J.N., Fox T.C., Estrada-Lüna A., and Ferrera-Cerrato R., 2002. Short term effects of Glomus claroideum and Azospirillum brasilense on growth and root acid phosphatase activity of Carica papaya L. under phosphorus stress. Rev. Latinoam. Microbiol., 44(1), 31-37.

Antony A. and Singadhupe R.B., 2004. Impact of drip and surface irrigation on growth, yield and WUE of capsicum (Capsicum annum L.). Agric. Water Manag., 65(2), 121132. https://doi:10.1016/j.agwat.2003.07.003

Ardakani M.R., Pietsch G., Moghaddam A., Raza A., and Friedel J.K., 2009. Response of root properties to tripartite symbiosis between lucerne (Medicago sativa L.), rhizobia and mycorrhiza under dry organic farming conditions. Am. J. Agric. Biol. Sci., 4, 266-277. https://doi:10.3844/ ajabssp.2009.266.277

Azcon R. and Barea J.M., 1976. Synthesis of auxins, gibberellins and cytokinins by Azotobacter vinelandii and Azotobacter beijerinckii related to effects produced on tomato plants. Plant Soil, 43, 609-613. https://doi. org/10.1007/BF01928522
Azimi R., Gang Ju M., and Asgari H.R., 2013. The effect of mycorrhiza inoculation on the initial establishment and morphological traits of the Thymus vulgaris under natural conditions (in Persian). Iranian J. Field Crop Res., 11(4), 666-676. https://doi.org/10.22067/GSC.V11I4.32903

Baldwin I.T., 2001. An ecologically motivated analysis of plant herbivore interactions in native tobacco. Plant Physiol., 127, 1449-1458. https://doi.org/10.1104/pp.010762

Bashan Y. and de-Bashan L.E., 2005. Plant Growth-Promoting. Encyclopedia. Soils Environ., 1, 103-115. https://doi.org/10.1016/B0-12-348530-4/00513-0

Baum C., El-Tohamy W., and Gruda N., 2015. Increasing the productivity and product quality of vegetable crops using arbuscular mycorrhizal fungi: a review. Sci Hort., 87, 131141. https://doi.org/10.1016/j.scienta.2015.03.002

Behrooz A., Vahdati K., Rejali F., Lotfi M., Sarikhani S., and Lesile C., 2019. Arbuscular mycorrhiza and plant growthpromoting bacteria alleviate drought stress in walnut. Hort. Science, 54(6), 1087-1092. https://doi.org/10.21273/HORTSCI13961-19

CORESTA, 1994. CORESTA recommended method No 35. Determination of total alkaloids (as nicotine) in tobacco by continuous flow analysis. https://www.coresta.org/sites/ default/files/technical_documents/main/CRM_35-update (Aug10) pdf.

Dai A., 2012. Drought under global warming: a review. Wires Clim Chg., 2, 45-65. https://doi.org/10.1002/wcc.81

Downie A., Crosky A., and Munroe P., 2009. Physical properties of biochar. In: Biochar for Environmental Management: Science and Technology (Eds J. Lehmann, S. Joseph). London, Earthscan.

Dixon R.K., Rao M.V., and Garg V.K., 1993. water relations and gas exchange of mycorrhizal Leucaena leucocephala seedlings. Trop. For. Sci., 6, 542-552.

El-Sawah AM., El-Keblawy A., Ali D.F.I., Ibrahim H.M., El-Sheikh M.A., Sharma A., Alhaj Hamoud Y., Shaghaleh H., Brestic M., Skalicky M., Skalicky M., Xiong Y.C., and Sheteiwy M., 2021. Arbuscular mycorrhizal fungi and plant growth-promoting rhizobacteria enhance soil key enzymes, plant growth, seed yield, and qualitative attributes of guar. Agriculture, 11(3), 194. https://doi.org/10.3390/agriculture11030194

Gao C., El-Sawah AM., Fathi Ismail Ali D., Alhaj Hamoud Y., Shaghaleh H., and Sheteiwy M.S., 2020. The integration of bio and organic fertilizers improve plant growth, grain yield, quality and metabolism of hybrid maize (Zea mays L.). Agronomy, 10(3), 319.

https://doi.org/10.3390/agronomy10030319

Gebhardt M., Fehmi J.S., Rasmussen C., and Gallery R.E., 2017. Soil amendments alter plant biomass and soil microbial activity in a semi-desert grassland. Plant Soil, 419, 53-70. https://doi.org/ 10.1007/s11104-017-3327-5

Giovannetti M. and Mosse B., 1980. An evaluation of techniques for measuring vesicular arbuscular mycorrhizal infection in roots. New Phytol., 84(3), 489-500. https://doi:10.1111/j.1469-8137.1980.tb04556.x

Gul S. and Whalen J.K., 2016. Biochemical cycling of nitrogen and phosphorus cycling in biochar amended soils. Soil Biol. Biochem., 103, 1-15. https://doi.org/10.1016/j. soilbio.2016.08.001 
Hammer E.C., Forstreuter M., Rillig M.C., and Kohler J., 2015. Biochar increases arbuscular mycorrhizal plant growth enhancement and ameliorates salinity stress. Appl. Soil Ecol., 96, 114-121.

https://doi.org/10.1016/j.apsoil.2015.07.014

Hashem A., Kumar A., Al-Dbass A.M., Alqarawi A.A., Al-Arjani A.B.F., Singh G., Farooq M., and Abd-Allah E.F., 2019. Arbuscular mycorrhizal fungi and biochar improves drought tolerance in chickpea. Saudi J. Biol. Sci., 26, 614-624. https://doi.org/10.1016/j.sjbs.2018.11.005

Ilkaee M.N., Paknejad F., Zavareh M., Ardakani M.R., and Kashani A., 2011. Prediction model of leaf area in soybean (Glycine $\max$ L.). Am. J. Agric. Biol. Sci., 6, 110-113. https://doi.org/10.3844/ajabssp.2011.110.113

Ju X.T., Chao FC., Li C.J., Jiang R.F., Christie P., and Zhang F.S., 2008. Yield and nicotine content of flue-cured tobacco as affected by soil nitrogen mineralization. Pedosphere, 18(2), 227-235. https://doi.org/10.1016/S1002-0160(08)60011-9

Kim Y., Oh J.-I., Vithanage M., Park Y.-K., Lee J., and Kwon E.E., 2019. Modification of biochar properties using $\mathrm{CO}_{2}$. Chemical Eng. J., 372, 383-389. https://doi.org/10.1016/j. cej.2019.04.170

Laird D.A., 2008. The charcoal vision: a win-win-win scenario for simultaneously producing bioenergy, permanently sequestering carbon, while improving soil and water quality. Agron. J., 100, 178-181.

https://doi.org/10.2134/agronj2007.0161

Larsen J., Pineda-Sánchez H., Delgado-Arellano I., CastellanoMorales V., Carreto-Montoya L., and Villegas-Moreno J., 2017. Interactions between microbial plant growth promoters and their effects on maize growth performance in different mineral and organic fertilization scenarios. Rhizosphere, 3, 75-81.

https://doi.org/10.1016/j.rhisph.2017.01.003

Major J., Rondon M., Molina D., Riha SJ., and Lehmann J., 2010. Maize yield and nutrition during 4 years after biochar application to a Colombian savanna oxisol. Plant Soil, 333, 117-128. https://doi.org/10.1007/s11104-010-0327-0

Mardukhi B., Rejali F., Daei G., Ardakani M.R., Malakouti M.J., and Miransari M., 2015. Mineral uptake of mycorrhizal wheat (Triticum aestivum L.) under salinity stress. Commun. Soil. Sci. Plant Analysis, 46, 343-357. https:// doi.org/10.1080/00103624.2014.981271

Mehari Z.H., Elad Y., Rav-David D., Graber E.R., and Harel Y.M., 2015. Induced systemic resistance in tomato (Solanum lycopersicum) against Botrytis cinerea by biochar amendment involves jasmonic acid signaling. Plant Soil, 395, 31-44.

https://doi.org/10.1007/s11104-015-2445-1

Mickan B., 2014. Mechanisms for alleviating of water stress involving arbuscular mycorrhizal fungi. In: Mycorrhizal Fungi: Use in Sustainable Agriculture and Land Restoration (Eds Z.M. Solaiman, L.K. Abbott, A. Varma). Soil Biol., 41, 225-239. https://doi:10.1007/978-3-662-45370-4_14

Miri M.R., Tohidi Moghadam H.R., Ghooshchi F., and Zahedi H., 2013. Effect of Azotobacter and Arbuscular mycorrhizal colonization enhance wheat growth and physiological traits under well-watered and drought conditions. J. Advances Environ. Biol., 7(14), 4630-4636.

Moosavi SA., Shokuhfar A., Lak S., Mogaddam M., and Alavifazel M., 2020. Integrated application of biochar and bio-fertilizer improves yield and yield components of cowpea under water-deficient stress. Ital. J. Agron., 15, 94-101. https://doi.org/10.4081/ija.2020.1581

Oppong Danso E., Yakubu A., Arthur E., Sabi E.B., AbenneyMickson S., and Andersen M.N., 2020. Effect of rice straw biochar and irrigation on growth, dry matter yield and radiation-use efficiency of maize grown on an Acrisol in Ghana. J. Agron. Crop Sci., 206, 296-307.

https://doi.org/10.1111/jac. 12383

Pasban Eslam B., Monirifar H., and Sadeghi Bakhtavari A.R., 2017. Morpho-physiological response of rapeseed (Brassica napus L.) genotypes to drought stress. Crop Breed. J., 7, 49-56. https://doi.org/10.22092/cbj.2018.116331.1019

Phillips J.M. and Hayman D.S., 1970. Improved procedures for clearing roots and staining parasitic and vesicular arbuscular mycorrhizal fungi for rapid assessment of infection. Trans. British Mycolog. Society, 55, 158-161.

Samarbakhsh S., Rejali F., Ardakani M.R., Nejad F.P., and Miransari M., 2009. The combined effects of fungicides and arbuscular mycorrhiza on corn (Zea mays L.) growth and yield under field conditions. J. Biol. Sci., 9, 372-376. https://doi.org/10.3923/jbs.2009.372.376

Saribay G.F., 2003. Growth and nitrogen fixation dynamics of Azotobacter chroococcum nitrogen-free and OMW containing medium. M.Sc. Thesis, The Graduate School of Natural and Applied Sciences, Middle East Technical University, Turkey.

Shang X., Shang Y., Fu J., and Zhan T., 2017. Nicotine significantly improves chronic stress-induced impairments of cognition and synaptic plasticity in mice. Molecular Neurobiol., 54, 4644-4658. https://doi.org/10.1007/s12035-016-0012-2

Sharma A.K., 2002. Biofertilizers for Sustainable Agriculture. Agro-Bios, Jodhpur India.

Sheteiwy M.S., Ali D.F.I., Xiong Y.C., Brestic M., Skalicky M., Alhaj Hamoud Y., Ulhassan Z., Shaghaleh H., AbdElgawad H., Farooq M., Sharma A., and El-Sawah A.M., 2021. Physiological and biochemical responses of soybean plants inoculated with Arbuscular mycorrhizal fungi and Bradyrhizobium under drought stress. BMC Plant Biol., 21, 195.

https://doi.org/10.1186/s12870-021-02949-z

Smart R. and Bingham G., 1974. Rapid estimates of relative water content. Plant Physiol., 53, 258-260.

Soliman M.H., Abdulmajeed A.M., Alhaithloul H., Alharbi B.M., El-Esawi M.A., Hasanuzzaman M., and Elkelish A., 2020. Saponin biopriming positively stimulates antioxidants defense, osmolytes metabolism and ionic status to confer salt stress tolerance in soybean. Acta Physiol. Plant, 42, 114. https://doi.org/10.1007/s11738-020-03098-w

Suliman W., Harsh J.B., Abu-Lail N.I., Fortun A.M., Dallmeyer I., and Garcia Pérez M., 2017. The role of biochar porosity and surface functionality in augmenting hydrologic properties of a sandy soil. Sci. Total Environ., 574, 139-147. https://doi.org/10.1016/j.scitotenv.2016.09.025

Syamsiyah J. and Herawati A., 2018. The potential of arbuscular mycorrhizal fungi application on aggregrate stability in alfisol soil. In Proceedings of the IOP Conference Series: Earth Environ. Sci., Surakarta, Indonesia, 142, 012045. https://doi.org/10.1088/1755-1315/142/1/012045 
Tarnabi Z.M., Iranbakhsh A., Mehregan I., and Ahmadvand

R., 2019. Impact of arbuscular mycorrhizal fungi (AMF) on gene expression of some cell wall and membrane elements of wheat (Triticum aestivum L.) under water deficit using transcriptome analysis. Physiol. Mol. Biol. Plant, 26(1), 143-162. https://doi.org/10.1007/s12298-019-00727-8

Tso TC., 1990. Production, Physiology, and Biochemistry of Tobacco Plant. Ideals Inc., Beltsville, ML, USA.

Van der Heijden M.G., Martin F.M., Selosse M.A., and
Sanders I.R., 2015. Mycorrhizal ecology and evolution: the past, the present, and the future. New Phytol., 205, 1406-1423. https://doi.org/10.1111/nph.13288

Wu Q.S. and Zou Y.N., 2009. Mycorrhiza has a direct effect on reactive oxygen metabolism of drought-stressed citrus. Plant Soil Environ., 55, 436-442. https://doi.org/10.17221/61/2009-PSE

Xiang Y., Deng Q., Duan H., and Guo Y., 2017. Effects of biochar application on root traits. GCB Bioenergy, 9, 1563-1572. https://doi.org/10.1111/gcbb.12449 